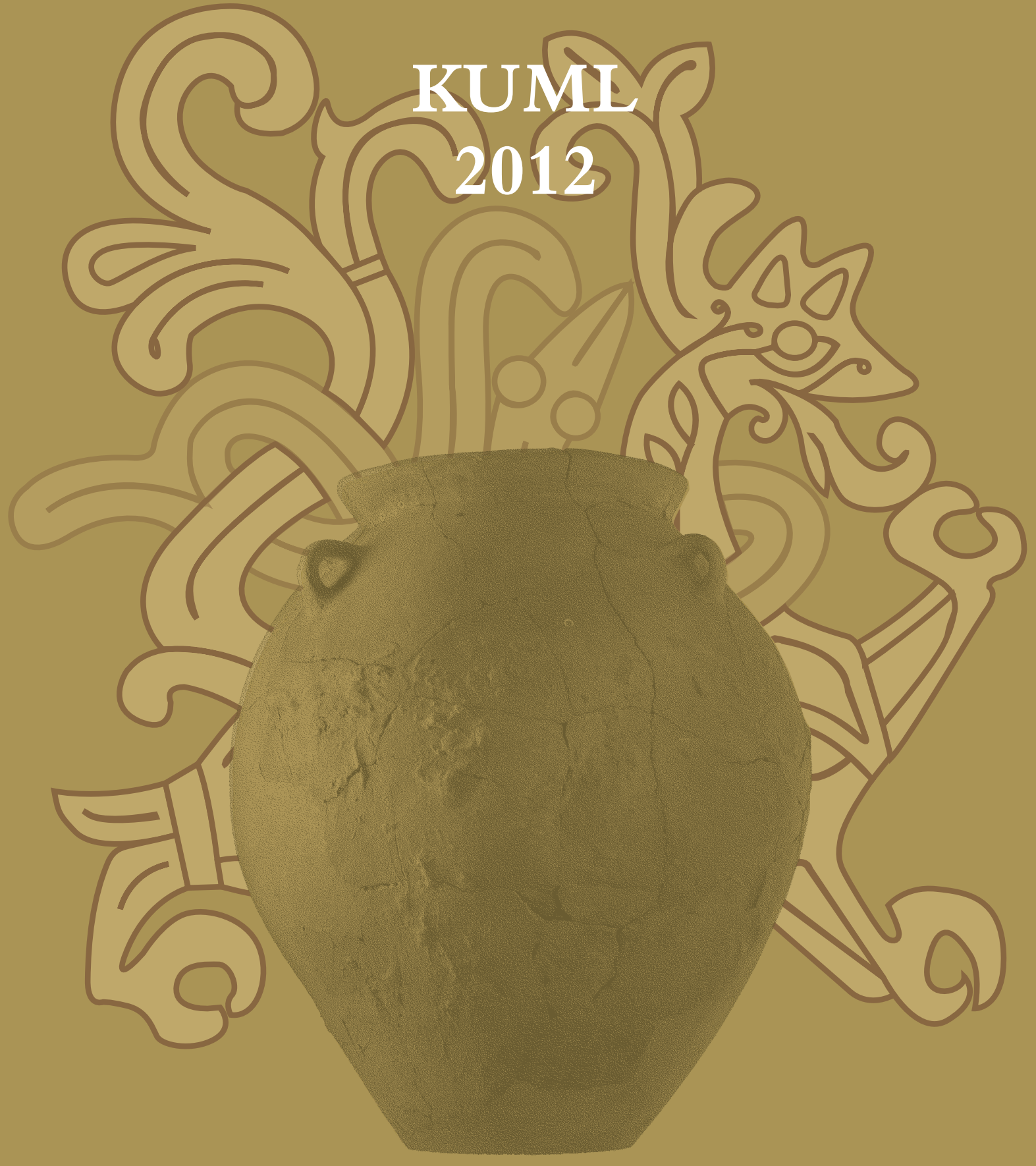




\section{KUML 2012}

Årbog for Jysk Arkæologisk Selskab

With summaries in English

I kommission hos Aarhus Universitetsforlag 


\section{"Vikinger", vikingetid og vikingeromantik}

Formålet med denne artikel er på den ene side at kaste et kritisk blik på den måde, hvorpå vi bruger begrebet "viking", og på den anden side at overveje, hvorvidt skandinavisk aktivitet i det, der har fået betegnelsen "vikingetiden", virkelig var af en sådan art, at den berettiger til at lægge navn til en epoke i europæisk historie. For da udtrykket vikingetiden først begyndte at blive anvendt, blev ordet viking udtrykkeligt og entydigt anvendt om personer af skandinavisk herkomst. Men var det nu også tilfældet i vikingetiden?

For at belyse dette må vi starte med nogle betragtninger over begrebet viking.

\section{Begrebet viking}

I det bevarede kildemateriale i bred forstand har udtrykket viking haft to liv i forskellige hverdagssprog og til forskellige tider med - i bedste fald - begrænset semantisk sammenfald. Når der her bruges udtrykket "det bevarede kildemateriale”, dækker det over, at ordet utvivlsomt har sin oprindelse i en tid, der ligger længe før såvel vikingetiden som de nu bevarede skriftlige kilder, der indeholder ordet. Det vender vi tilbage til.

Mens udtrykket vikings første liv som levende ord i et hverdagssprog endte allerede inden middelalderens udgang - måske med undtagelse af islandsk - så fik det nyt liv i årene umiddelbart for eller efter år 1800, da man begyndte at anvende det om skandinaviske krigere og sørøvere ofte med heroiske træk.

De fleste vikingetidsforskere er sandsynligvis bevidste om, at udtrykket viking som personkarakteristik ikke var særlig udbredt i vikingetiden. Og hvis vi nu for et øjeblik antager, at det var et ord, der anvendtes specifikt om skandinaver, så var det i hvert fald sjældnere end variationer over nortmanni, der hovedsageligt optræder i latinske tekster, eller nogle af de snævrere etniske betegnelser, der dengang var i brug. I modsætning hertil anvendtes udtrykket "viking” overhovedet ikke om skandinaver i skandinavernes østlige sfære, hvor 
der i stedet anvendtes variationer af rus' eller varegere/veringer i østslaviske, græske og arabiske kilder.

Som levende ord i et hverdagssprog under vikingetiden ses viking tilsyneladende kun i oldengelsk, oldnordisk og måske i nogle andre germanske sprog som oldfrisisk.

I betragtning af kildesituationen overrasker det ikke, at det blandt disse sprog tidligst er belagt i oldengelsk. Her findes det først og fremmest i visse oldengelske glossarier, der i overensstemmelse med dateringen af i det mindste ét håndskrift senest stammer fra slutningen af 600-tallet; altså ca. 100 år før vikingetiden traditionelt antages at begynde med de skandinaviske plyndringer af klostre på De britiske Øer i slutningen af 700-tallet. I disse glossarier angives oldengelske modsvarigheder til latinske ord, og som modsvarighed til det latinske piraticus finder vi så her det oldengelske wicing. Det sker, uden at der knyttes etniske eller geografiske associationer til ordet. ${ }^{1}$

Desuden forekommer wicing i et antal oldengelske poetiske værker, hvis datering er omstridt, men som findes i håndskrifter fra ca. år 1000. ${ }^{2}$ Endelig er der tre forekomster i de angelsaksiske krøniker. ${ }^{3}$ Den præcise betydning her er uklar. Det vender vi kort tilbage til.

Ved siden af de oldengelske kilder forekommer viking i oldnordiske tekster. Ældst er her runeindskrifter hovedsageligt fra 1000 -tallet. Her omtales personer, der

1) på forskellige steder siges at dø/være "i viking":

"Faðir lod hugge disse runer til minde om Ôzurr, sin broder, som døde i nord i viking" (DR 334); ${ }^{4}$

"Tóla satte denne sten til minde om Geirr, sin søn, en god og tapper mand. Han døde på vestvejen i Viking” (VG 61);

"Tosti(?) og Gunnarr ... disse sten til minde om Kn ... [og] ...-bjørn, deres fæller. Disse drenge var v[idt kendte?] i viking" (DR 330). ${ }^{6}$

2) at have slået følge med vikinger:

"Hvatarr(?) og Heilgeirr(?) rejste sten efter Helgi, deres far. Han var rejst vest med vikinger" (G 370).?

3) eller hjemme at have fungeret som vagt mod vikinger, en åbenbart fortjenstfuld opgave:

"Ginnlaug, Holmgeirrs datter, Sigrøðr og Gautrs søster, hun lod gøre denne bro og rejste denne sten til minde om Assur, sin (hus)bond, Hákon jarls søn. Han var vikingevagt med Geitir(?). Hjælp nu Gud hans ånd og sjæl" (U 617). ${ }^{8}$ 
Oftest forekommer viking dog i sagalitteraturen, der, som den er bevaret, er skrevet eller kopieret fra det sene 1100-tal og fremover, mens ordet stadig var en del af hverdagssproget og derfor kan have bevaret det betydningsindhold, det havde i de tidligst kendte tekster.

I disse oldnordiske tekster bruges viking om plyndrende krigere eller sørøvere, der drog "i viking" eller kom "fra viking", svarende til de belæg vi fandt i runeindskrifterne. Disse belæg må indebære, at de pågældende enten slog følge med andre som krigere for at plyndre et eller andet sted i eller uden for Skandinavien eller vendte hjem fra sådanne foretagender. Flere af disse belæg citeres nedenfor i anden sammenhæng.

En refleks af denne oldnordiske sprogbrug er forekomsten af udtrykket hos Adam af Bremen:

"Der [på Sjælland] findes meget guld, der samles på sørøvertogter. Sørøverne som de kalder wichinger, vi ascomanner, betaler tribut til den danske konge for at få lov til at udplyndre de barbarer, der talrigt bor omkring dette hav".

Som det gjaldt for de oldengelske belæg, fremgår det af de oldnordiske belæg, at $\mathrm{i}$ vikingetiden var en skandinav ikke en viking, blot fordi han var skandinav. Det var en funktion, han kunne vælge og så fravælge igen. Præcis som vi læser i Egils saga Skalla-Grimssonar om en vis Bjørn:

"Bjørn var en stor sømand - sommetider i viking, sommetider på købmandsfærd". 10

\section{Jagten på en etymologi ${ }^{11}$}

I den omfattende litteratur om vikinger kan det undre, at så mange forskere bruger tid og plads på at udfinde en etymologi for viking frem for blot at konstatere, hvordan ordet faktisk blev brugt i den periode, hvori det er belagt. ${ }^{12}$ Stort set alle fremstillinger med vikinger i centrum indledes med kortere eller længere afsnit, der diskuterer og sommetider påstår, at ordet kommer af dette eller hint. Kendetegnende for mange af disse fremstillinger er, at de uden særligt vægtige argumenter med flid når til et andet resultat end det senest forud publicerede værk inden for de samme fire til fem løsningsforslag: at ordet skulle knytte sig til 1) oldengelsk wic (lejr); 2) oldnordisk vik (bugt); 3) verbet vikja (afvige (fra rute)); 4) oldnordisk uikasio (skifte (af rohold under sejlads)); 5) indbyggere af det norske område Viken. Sidstnævnte teori er den eneste, der udtrykkelig knytter ordet viking til skandinaver og Skandinavien. ${ }^{13}$

Alt i alt forekommer det usandsynligt, at nogen på grundlag af et så relativt begrænset materiale skulle kunne udtænke en teori, der hviler på så solide 
argumenter, at det vil kunne overbevise tilhængere af alternative teorier. Så meget desto mere som de oldengelske glossarier viser, at ordet må være betragteligt ældre end de få vikingetidsbelæg.

Desuden, og dette er principielt vigtigt, har forskerne i denne jagt på en etymologi været præcis så ensporede, som meget af vikingetidens forskning $\mathrm{i}$ almindelighed er. De ser kun mod vest og beskæftiger sig alene med forekomsten af ordet i germanske sprog. Men trods det indtryk, man kan få ved at læse vikingeforskningens mange værker, så var skandinaver på den tid mindst lige så aktive i øst, som de var i vest. Men ingen etymologister synes at interessere sig for mulige spor af ordet viking i østlige sprog. For skønt ordet viking, som det blev nævnt i indledningen, aldrig bruges om skandinaver i øst, så betyder det ikke, at ordet ikke har været kendt i og ikke har øvet indflydelse på østlige sprog. Her tænkes især på slaviske sprog.

Sagen er, at lige siden den kendte slavist Valentin Kiparsky i 1934 publicerede sin disputats, "Die gemeinslavischen Lehnwörter aus dem Germanishen", har det været kendt blandt lingvister, at det fællesslaviske *vitęd'źb (helt, kriger), der i variationer findes i alle nutidige slaviske sprog, kommer af et germansk viking. ${ }^{14}$ En opfattelse der siden er blevet kanoniseret i den tysk-russiske sprogforsker Max Vasmers grundlæggende russisk etymologiske ordbog fra 1950'erne. Heri kan vi læse, hvordan modsvarigheder til det moderne russiske vítiaz' findes belagt i alle kendte slaviske sprog med forskellige videre betydningsudviklinger. Det ses også, hvorledes ordet fra slaviske sprog er blevet lånt videre til baltiske sprog og endog tilbage til germanske sprog i områder, som i korstogstiden og senere koloniseredes af germanske folk fra tyske, frisiske og hollandske områder. Vasmers entydige konklusion er, at det slaviske ord "utvivlsomt via et *vitędzb er et lån fra et germansk *víking". ${ }^{15}$

Siden har den polske lingvist Zbigniew Goląb argumenteret for, at det slaviske ord er udgået fra germansk *wikkingaz, som sandsynligvis er afledt af et weihan (wīhan i gotisk) "kamp". Som det også blev fremført af Kiparsky, understreger Goląb, at denne slaviske ækvivalent til viking hører til det ældste lag af germanske låneord i slavisk fra de første århundreder af vor tidsregning. ${ }^{16}$

Dette stiller de traditionelle vikinge-etymoligisters jagt på en etymologi i et lidt tvivlsomt lys.

\section{Er vikinger skandinaver?}

Indledningsvist blev det sagt, at ordet viking har haft to liv i hverdagssprog. I dets andet, moderne liv er viking både blevet brugt som substantiv og adjektiv. Som substantiv er det udelukkende blevet anvendt om skandinaver. Tidligst 
anvendtes det om begrænsede grupper af sørøvere og krigere, men efterhånden blev det udbredt til at omfatte vikingetidens skandinaver i bred almindelighed; og i dag, i turistindustrien m.m., indbefatter det nu også nutidige skandinaver. I forlængelse af denne moderne skandinaviske sprogbrug bliver viking både som substantiv og adjektiv i dag anvendt i stort set alle sprog om alt skandinavisk.

Som det er fremgået, synes det samme ikke at være tilfældet i vikingetiden. Godt nok er der næppe tvivl om, at langt de fleste gange viking ses brugt i vikingetidens kilder, så bruges det om skandinaver. Det hænger imidlertid først og fremmest sammen med, at en stor del af de relevante kilder, især sagalitteraturen, sjæeldent omhandler andet end skandinaver og deres aktiviteter inden for eller uden for Skandinavien. Tilsvarende tenderer de "wicingas", der optræder i de angelsaksiske krøniker og i et digt som "The Battle of Maldon", mod at være hærgende skandinaviske krigere, alene fordi skandinaver, da disse kilder blev til, faktisk var særdeles aktive krigere på De britiske Øer. Ikke desto mindre synes det umuligt at finde så meget som ét tilfælde, hvor det alene er forekomsten af et viking/wicing i en skandinavisk eller oldengelsk kilde, der gør denne til skandinav; derimod er det alene den sammenhæng, hvori en viking/wicing optræder, der gør det muligt for os at bestemme, til hvilken etnisk eller geografisk gruppe den pågældende person hører.

Det nærmeste, vi kommer på, at et wicing umiddelbart synes at angive et etnisk - og da muligvis skandinavisk - tilhørsforhold, er nok digtet Widsið. Widsið består af 143 vers i form af en rejsebeskrivelse foretaget af den foregivne poet Widsið. Digtet dateres til forskellige tider inden for sidste halvdel af det første millennium, men er bevaret $i$ et enkelt håndskrift fra omkring år 1000, så yngre er det ikke. I de fleste vers opregner Widsið konger, folk eller andre grupperinger, han har rejst med eller iblandt.

I denne liste optræder wicing to gange og en tredje i sammensætningen Lidwicingas. Af disse er den første forekomst, der er relevant. Her læser vi i linje 47 om et "wicinga cynn": "sippan hy forwræcon wicinga cynn". ${ }^{17}$ Denne sekvens findes i forskellige engelske tolkninger, der på dansk kan gengives således: 1) "efter de havde fordrevet Wicingas-stammen", ${ }^{18} 2$ 2) "efter de havde besejret Viking racerne"; ${ }^{19}$ eller 3) helt uden brug af wicing: "efter de havde fordrevet Heathobard-stammen". ${ }^{20}$ Spørgsmålet er her, om udtrykket cynn (moderne engelsk: "kind") i "wicinga cynn" virkelig står for race eller stamme i etnisk eller geografisk betydning, eller om det står for en gruppe, der kendetegnes ved andre fælles træk såsom for eksempel at være sørøvere eller krigere. Udtrykket "cynn" forekommer yderligere tre gange i digtet: to gange i betydningen menneskeheden (mankind: "monna cynnes" og "moncynnes") og en 
gang i formen "Fresna cynne". Det sidste tolkes sædvanligvis som frisere, og på den baggrund kunne det også være nærliggende tilsvarende at se "wicinga cynn" som en etnisk eller geografisk defineret gruppe. En sådan tolkning finder imidlertid næppe støtte i forbindelse med den anden forekomst af "wicingas" (linje 57-60), i hvert fald ikke hvis "wicingas" antages at stå for skandinaver:

"Jeg var med hunner og med hreðgoter, med svenskere og geater og med syddanskere, med wenlere jeg var med wernere og med vikinger ...”.

Pointen er her, at både i denne sekvens og andetsteds i digtet omtales en række skandinaviske grupper ved deres etnisk eller geografisk bestemte navne: jyder, danere, sø-danere, svenskere, göter (det er sandsynligvis, hvad geater står for i den citerede tekst, eftersom goter nævnes særskilt). Derfor er det usandsynligt, at "wicingas" her skulle stå for skandinaver som sådan eller for en undergruppe heraf; derfor kan man næppe heller bruge Widsiðs "wicinga cynn" som belæg for at påstå netop det. ${ }^{21}$

Er det således vanskeligt at finde bare ét eksempel på, at udtrykket wicing/viking i sig selv skulle udpege en person som skandinav, så kræver det til gengæld kun ét belæg i en vikingetidskilde, hvor wicing/viking beviseligt anvendes om nogen, der ikke er skandinav, for at vise at ordet intet har med skandinavisk etnicitet at gøre. Af sådanne belæg er der imidlertid adskillige.

Starter vi igen med de ældste, oldengelske tekster, så finder vi udtrykket "sæwicingas" i den oldengelske gendigtning, Exodus, af 2. Mosebogs beskrivelse af Israels udvandring fra Ægypten. Digtet dateres til tidsrummet 7001000, hvor sidstnævnte år modsvarer dateringen af det ældst bevarede manuskript. Udtrykket forekommer i en sekvens, hvor israelitterne, "Rubens sønner", idet de forcerer det Røde Hav, kaldes "sæwicingas". ${ }^{22}$ - Disse "havvikinger" kan den oldengelske forfatter umuligt have forestillet sig skulle være skandinaver.

De oldnordiske vidnesbyrd er selvfølgelig senere, men til gengæld langt talrigere. De findes i sagalitteraturen, hvor de også kan findes i de indeholdte skjaldedigte, der antageligt er samtidige med det beskrevne. Her kan vi i Snorres Heimskringla finde disse eksempler (mine kursiveringer):

Olafs Tryggvasons saga, kap. 6: "Men da de holdt mod øst i havet, kom vikinger imod dem, det var Ester; ..... ${ }^{23}$

Harald Hårderådes saga, kap. 48: “... dér blev Håkon kong Svends landeværnsmand mod vikinger, som ofte hærgede Danevældet, Vender og Kurer og andre Østervejsmand" ${ }^{24}$ 
Magnussønnernes saga, kap. 4: "Da kong Sigurd [Jorsalfar] sejlede langs Spanien, skete det, at nogle vikinger, som var på hugst, kom imod ham med en har af galejer; men kong Sigurd lagde an til strid med dem, og det var hans første kamp imod hedenske mænd; han vandt otte galejer fra dem". ${ }^{25}$

I Knytlingesagaen, kap. 29 finder vi denne tekst vedrørende Knud den Hellige, der prises for at skaffe ro og orden i landet efter forgængeren Harald Hén, for mens Harald:

"havde været konge over Danmark var ugerninger kun i ringe grad blevet straffet, hverken de der blev begået af landets egne folk eller af vikinger, som dengang hærgede i Danmark, både Kurere og andre mænd fra Østerleden". ${ }^{26}$

Endelig finder vi i Yngvars saga vífförla en beretning om et møde mellem Ingvar og hans følge med fjendtlige lokale vikinger et sted i Kaukasus. ${ }^{27}$

Med andre ord: mens udtrykkene wicing/víking endnu levede i de oldengelske og oldnordiske hverdagssprog, blev de brugt uden nogen bestemt etnisk eller geografisk tilknytning. Ordene kunne bruges om alle, hedninge, kristne eller muslimer, hvis disse fremstod som sørøvere eller krigeriske modstandere til de angelsaksere eller skandinaver, der beskrev dem som vikinger. Det gjaldt, hvad enten handlingen var henlagt til det Hellige Land, langs den spanske kyst, i Kaukasus, i Østersøområdet eller hjemme i Skandinavien. Det vil sige viking kunne bruges om stort set alle i hele det område, der befærdedes af skandinaver i den periode, vi nu kalder vikingetiden, når de blot optrådte i en funktion, der modsvarede vikingegerningen.

Hvad er der sket siden da, der har kunnet bevirke, at viking i dag eksklusivt bruges om skandinaver?

\section{Vikingen uddør - midlertidigt}

Når vi har kunnet tale om ordet vikings andet liv, skyldes det, at det tilsyneladende forsvandt som levende ord i såvel engelsk som de nordiske sprog omkring 1300 med mulig undtagelse af islandsk. Konsulterer vi således Otto Kalkars "Ordbog til det ældre danske Sprog" fra 1907, så finder vi ikke ordet viking. ${ }^{28}$ Hvad angår svensk, så er "Svenska Akademiens Ordbog", der har til hensigt at beskrive den ældre ordskat, godt nok endnu ikke nået til bogstavet "v", skønt projektet allerede har mere end 100 år på bagen. ${ }^{29}$ Det er dog ret sikkert, at ordet viking ikke findes i det trods alt begrænsede svenske kildemateriale fra middelalderen efter runeindskrifternes tid. ${ }^{30}$ 
Norsk blev på sin side i løbet af senmiddelalderen og nyere tid mere eller mindre fortrængt af dansk som selvstændigt sprog. Da en norsk sprogforsker, Ivar Aasen, under indflydelse af Romantikken ønskede at genskabe et norsk sprog og derfor rejste rundt i Norge for at botanisere i de norske dialekter, faldt han godt nok over ordet viking, men ikke i nogen betydning, det havde haft i vikingetiden, nemlig: "Viking, m[askulinum]. Indbygger af et Sted eller Distrikt med Navn af Vig". ${ }^{31}$

Ordet viking, som det brugtes i vikingetiden, dukkede først op igen, da danske og svenske renæssancehistorikere begyndte at konkurrere med hinanden om at skabe deres lande så glorværdig en fortid som muligt. I den forbindelse begyndte de at lede efter anvendeligt kildemateriale og fik da også øje på sagalitteraturen. Snart begyndte de derfor at rekvirere håndskrifter fra Island. Problemet var imidlertid, at ingen længere forstod oldislandsk, historikerne blev derfor afhængige af oversættelser. De første så dagens lys i slutningen af 1500-tallet, og snart blev en af de mere omfattende oversættelser også trykt. Det drejer sig om en lettere forkortet oversættelse til dansk af Snorres Heimskringla af præsten Peder Claussøn Friis og udgivet posthumt af Ole Worm i $1633 .{ }^{32}$

Denne oversættelse er yderst interessant, netop hvad angår ordet viking. En analyse af de steder i Snorres tekst, som indgår i Friis' oversættelse, og hvor Snorre bruger ordet viking, viser nemlig tydeligt, at Friis var sikker på, at ingen af hans danske læsere ville vide, hvad en viking var. Derfor gengav Friis kun få gange viking med blot og bart viking. I stedet tilføjede han enten en forklaring til ordet, ofte i parentes, eller han omskrev teksten fuldstændigt. I disse illustrative eksempler er Friis' fordanskning indføjet i skarp parentes [] i Snorres originaltekst, mens de tilføjelser eller omskrivninger, Friis foretog, er kursiveret; sideangivelserne er til udgaven fra $1633 .{ }^{33}$

1) Hann var hermaður mikill og var löngum í víkingu og fékk sér fjár. [lenge udi viking / det er / Siørffuerij / oc samlede sig megit Gots oc Pendinge, s. 32] ...

2) Sölvi var síðan víkingur... [Solui Klofue bleff siden en Viking / (det er en Siørefrere), s. 45].

3) ... er pér farið hvert sumar í víking á önnur lönd [at I drage huer sommer at stride oc refue uden Lands, s. 91] ...

4) Orkneyjar en ádur var par víkingabæli. [[Orkneyøerne] hafde værit Vikingebøle (Det er Sørøfueris Bolig), s. 234].

5) Kálfur Árnason hafði verið í vesturvíking [Der Kalff Arnesøn var uden Lands refuede hand $i$ Vestersøen, s. 354] ...

6) Dá er Sigurðr konungr siglði fyrir Spán. barsk pat at, at víkingar nokkurir, peir 
er fóru at féfangi, kómu í móti honum með galeiða her. En Sigurðr konungr lagði til orrostu við pá, ok hófu svá ina fyrstu orrostu við heiðna menn, ok vann af peim viii galeiðr [der kom en heel Flaade Galeier med hedninger mod dennem, s. 403]. ${ }^{34}$

Det fremgår altså klart, at da viking genopstod i dansk sprogdragt omkring 1600, blev det af oversætteren dels forudsat, at det ikke ville blive forstået, og samtidig blev det af oversætteren tildelt betydningen sørøver og stridsmand. Med andre ord havde viking, da oversættelsen blev til, samme betydning, det havde haft næsten et årtusinde tidligere, da vi første gang finder ordet i det oldengelske glossarium. Desuden fremgår det klart, at ordet, da oversættelsen blev til, fortsat kunne anvendes om en hvilken som helst sørøver, hvad enten han var skandinav i hjemlige farvande, eller det var muslimer (her kaldt hedninge) i et fjernt område, som det fremgår af eks. 6, der netop vedrører Snorres beskrivelse af Sigurd Jorsalfars sejr over de galejsejlende vikinger i Middelhavet, som også blev citeret ovenfor. Det vil så også sige, at den betydning, hvori vi i dag bruger ordet viking, endnu var helt ukendt for Friis.

\section{Vikingen genopstår som skandinav}

Forvandlingen af vikingen fra at være en sørøver af en hvilken som helst oprindelse til, i første omgang, eksklusivt at være en skandinavisk sørøver i vikingetiden og siden, som i dag, en hvilken som helst skandinav, fortidig som nutidig, var en proces, der indledtes af skønlitterære forfattere under indflydelse af Romantikken. To svenske poeter kom til at spille hovedroller i denne proces: Erik Gustaf Geijer (1783-1847) og Esaias Tegnér (1782-1846).

Geijer var den, der med digtet Vikingen atter levendegjorde ordet viking i de skandinaviske hverdagssprog, men nu eksklusivt anvendt om skandinaver. Digtet kom i 1811 i det første nummer af Götiska förbundets tidsskrift, Iduna, der også indeholdt et andet af Geijers berømte digte, Manhem. Dette digt udgik af den svenske stormagtstids göticisme, der hidtil, siden 1400-tallet, havde inspireret svenske historikere i deres forsøg på at skabe Sverige en glorværdig fortid ved at knytte an til de goter, der i 400-tallet havde erobret Rom og grundlagt flere riger rundt om i Europa ${ }^{35}$ Denne samtidige fremkomst af de to digte, Vikingen og Manhem, i en og samme samling kan siges at markere et sceneskifte fra göticisme til noget, vi kan kalde vikingisme i forestillingen om, hvad storheden i svensk historie kunne baseres på. Et sceneskifte, der samtidigt peger frem mod skandinavismen, hvor de skandinaviske folk ikke længere konkurrerer på fortiden, men snarere ser sig som resultat af en fælles fortid. 
Tegnérs bidrag udgjordes af hans "Frithiofs Saga" (1820-25), der var en gendigtning af den oldnordiske Friðpjófs saga hins frokna. Muligvis inspireret af en nylig svensk oversættelse af Jomsvikinga Saga, ${ }^{36}$ indføjede Tegnér i forhold til originalen blandt andet en Vikingabalk, en slags lov for vikinger, ${ }^{37}$ der lod den skandinaviske viking fremstå i et glorværdigt lys. Derved bidrog Tegnér yderligere til det heroiske billede af den skandinaviske viking, Geijer havde skabt.

I første halvdel af 1800-tallet var det genopdagne ord viking endnu forbeholdt skønlitterære forfattere, der kun havde et beskedent kendskab til det samlede corpus af kilder, hvori viking forekom i vikingetiden, og ingen blandt disse forfattere betvivlede, at vikingen var en skandinavisk helt, sørøver eller ej. Da siden forskere omkring midten af 1800-tallet - svenskeren Anders Strinnholm en anelse tidligere end andre - lidt efter lidt begyndte at anvende ordet viking, overtog de det i den betydning, de nu kendte fra skønlitteraturen.

\section{Vikingetidens opkomst}

Da forskerne siden hen også begyndte at bruge udtrykket vikingetiden, forstod de dermed en periode, der domineredes af skandinaviske vikingers aktivitet hjemme og ude. Den danske arkæolog Jens Jacob Asmussen Worsaae anses ofte for at være den første, der knyttede ordet viking til en historisk periode, efter at han havde besøgt De britiske Øer og Normandiet og der havde identificeret fund som skandinaviske. ${ }^{38}$ Men, skønt Worsaae var arkæolog, var hans og andre samtidige forskeres datering af vikingetiden ikke baseret på de arkæologiske fund, som på den tid ikke kunne dateres med nogen præcision. Derfor blev dateringen, som den stadig er, baseret på de skriftlige kilder; og derfor er det også stadig de skandinaviske angreb på klostre på De britiske Øer, der anses for at danne indledningen til vikingetiden.

Mens det skriftlige kildemateriale i dag er stort set det samme, som det var på Worsaaes tid, så er mængden af arkæologiske kilder vokset med stadig stigende hast. Samtidig er metoderne til at datere og tolke dette materiale blevet stadig mere forfinede. Derfor tvinger det arkæologiske materiale os til i mange henseender at revidere vort syn på vikingetiden. Det gælder både vikingetidens karakter og dens kronologiske rammer. Først og fremmest har dendrokronologiske dateringer afsløret, at skandinaver var til stede på flere af de pladser, der blev centrale i det, der kan kaldes "vikingernes verden", længe før de nævnte angreb på britiske klostre sidst i 700-tallet. Det var tilfældet på De britiske Øer, ofte set som hovedscenen for skandinavisk aktivitet i vikingetiden, men det var i endnu højere grad tilfældet, når vi vender blikket mod øst. 


\section{Skandinaver i øst}

Den østlige dimension har aldrig spillet nogen stor rolle i vikingetidsstudier. En årsag til dette har været, at der var færre skriftlige kilder hertil, og at disse sammen med den videnskabelige forskning, der knytter sig til disse kilder, har været på sprog, vikingetidsforskere traditionelt ikke har behersket. Desuden optræder skandinaver i øst først relativt sent i de skriftlige kilder, nærmere bestemt 839 , mens de i de russiske krøniker optræder endnu senere: Fra 850'erne og fremover, hvis vi ellers godtager den tvivlsomme kronologi, vi præsenteres for i den såkaldte Nestorskrønike. Noget lignende gælder græske og arabiske kilder. På den baggrund ses beskrivelsen af skandinavernes østlige aktiviteter ofte begrænset til en efterskrift på fem til ti sider i generelle fremstillinger af vikingetiden.

I dag er situationen, når vi inddrager det arkæologiske kildematerieale, en helt anden, omend det ikke har sat sig nævneværdige spor i vikingetidsstudierne. Nu ved vi således, takket være dendrokronologiske dateringer, at skandinaver allerede ved midten af 700-tallet var trængt ind i det østeuropæiske flodsystem, hvor det fremtidige Rus'-rige skulle blive dannet. Således havde skandinaver omkring 750 etableret sig blandt den lokale østersøfinske befolkning i Staraja Ladoga ved Volkhov floden syd for Ladoga søen. ${ }^{39}$

Den skandinaviske indtrængen i dette område havde meget lidt med sørøveri og plyndring at gøre, fordi sørøvere ikke, dybt inde i et flodsystem, kunne regne med at slippe ud med deres bytte, med mindre de havde en magtkoncentration, som de lokale ikke kunne matche. Og en sådan magtkoncentration havde skandinaverne først, da de havde skabt Rus'-riget. Da kaldtes det ikke længere plyndring, men beskatning!

I stedet for røveri og plyndring drejede det sig i dette område primært om handel. I dag tillader arkæologiske data fra andre regioner at følge den proces, hvorved skandinaverne skabte det fjernhandelsnetværk, hvori Staraja Ladoga kom til at indgå. Som et af processens startpunkter i Skandinavien kan vi måske betragte anlæggelsen i det første decennium af 700-tallet af Ribe. På Ribe fulgte snart grundlæggelser af eller pludselig vækst i andre handelscentre i Østersøområdet, såsom Reric, Ralswiek, og Wolin blandt slaver; Truso, Wiskiauten og Grobin blandt baltere; Åhus i Skåne, forskellige pladser på Gotland og Birka blandt svenskere, og endelig, som nævnt, Staraja Ladoga blandt østersøfinner i den nordvestlige del af det nuværende Rusland. Andre vil sikkert komme til som følge af fremtidige udgravninger.

Et fælles træk ved alle disse handelspladser var, at udover de respektive lokalbefolkninger var skandinaver den eneste anden gruppe, der var til stede i alle disse centre. Et fænomen, der bliver desto mere udtalt, jo længere mod øst vi 
kommer. Således var skandinaver omkring 800, altså nogenlunde samtidig med at de første angreb i vest omtales i de skriftlige kilder, til stede ved to vigtige og delvist eksisterende handelscentre i det fremtidige Rusland langt nede ad Volga på ruten til Kalifatet: Sarskoe Gorodishche og Timerëvo nordøst for det nuværende Moskva. Det var ad den rute, de mange arabiske sølvmønter nåede Østersøområdet.

Opkomsten af dette handelsnetværk skal utvivlsomt ses som følge af en øget efterspørgsel i Vesteuropa efter varer, der fandtes i øst. Skandinavernes særlige rolle i dette kan måske tilskrives skibsmæssige innovationer, der har givet dem en dominerende fjernhandelsfunktion i det baltiske område. Det samarbejde, der opstod mellem lokalbefolkningerne og skandinaverne, tillod lokalbefolkningerne at få deres lokale produkter ud på et internationalt marked, og derfor har de haft en interesse i samarbejdet. Et samarbejde der siden har kunnet danne grundlag for politiske aftaler. Det må være det, der er sket langs en anden handelsrute, der etableredes lidt senere end Volgaruten, nemlig ruten fra Østersøen til Byzans, i russiske krøniker kendt som "Vejen fra Varægerne til grækerne".

Denne rute trafikeredes i det mindste fra første halvdel af 800 -tallet, men det var først omkring 900, at den pludselig voksede i betydning. På det tidspunkt begyndte skandinaver at oprette militære anlæg til støtte for handlen langs denne rute. I tillæg til Staraja Ladoga var der fra sidste halvdel af 800-tallet tale om Rjurikovo Gorodishche, tæt ved det fremtidige Novgorod, Gnëzdovo ved Dnjeprs øvre løb, en forløber for nutidens Smolensk, og Kiev. Desuden opstod et antal mindre fortifikationer, som nu er under udgravning som for eksempel Shestovitsa på floden Desna tæt ved Chernigov.

Det blev oprettelsen af disse militære støttepunkter, og den handel med Byzans de beskyttede, som dannede grundlag for opkomsten af det skandinavisk dominerede Rus'-rige, der med Kiev som centrum etableredes omkring år 900. At der på det tidspunkt var tale om en egentlig rigsdannelse, viser de internationale traktater, de skandinaviske Rus' indgik med de byzantinske kejsere i 907/11. Den efterfølgende traktat mellem Rus' og Byzans fra 944 viser ydermere, at den kristne religion på det tidspunkt havde opnået officiel status i Rus', og at det var skandinaver eller folk af skandinavisk oprindelse, der i første række var bærende i den proces. ${ }^{40}$

Denne begyndende statsdannelse var utvivlsomt det mest vidtrækkende resultat overhovedet af skandinavernes aktivitet under vikingetiden og fik en række varige konsekvenser, som vi alle kender til, men måske ikke tænker så meget over. For uden skandinavernes interesse i at skabe en fjernhandelsrute mellem Østersøen og Byzans, er det vanskeligt at forestille sig, hvorledes Rus- 
land, som det eksisterer i dag, skulle være blevet til: det var skandinaviske krigere og købmænd, der skabte en fælles interesse i lokalbefolkningerne for at indgå i dette handelsnetværk og dermed sammenknyttede et nordligt område omkring det fremtidige Novgorod, domineret af østersøfinske og baltiske folk, med det sydlige område omkring Kiev, domineret af østslaver.

Hvis skandinavisk aktivitet derfor fortjener at lægge navn til en epoke i europæisk historie, må det være på baggrund af det fjernhandelsnetværk, de etablerede mellem øst og vest, samt det Rus'-rige de skabte til støtte for dette handelsnetværk. Skal denne skandinaviske indsats ses som en epoke i europæisk historie, må den imidlertid i stedet for at dateres på grundlag af tilfældige plyndringer af klostre på De britiske Øer i slutningen af 700-tallet, dateres tilbage til begyndelsen af 700-tallet, da det skandinavisk dominerede handelsnetværk begyndte at tage form.

\section{Konklusion}

Vi står altså med en epoke, ca. 700-1100, hvor skandinaver rettelig kan siges at have spillet en betydelig rolle i europæisk historie. Imidlertid kolporteres denne epoke under den falske varebetegnelse vikingetiden takket være den forfejlede tilgang til kildematerialet, der, som her beskrevet, har gjort epokens vikinger til etniske skandinaver af heroisk tilsnit. Ydermere har denne forfejlede tilgang på forunderlig vis haft en sådan succes, at udtrykket viking, i den sekundære betydning det nu har fået, i dag fungerer som et brand for skandinaver, Skandinavien og skandinavisk overalt i verden. Her kan udtrykket viking forekomme $i$ alle tænkelige og utænkelige sammenhænge, og siden er denne viking ydermere blevet udstyret med en behornet hjelm i en sådan grad, at den nu alene i sig selv signalerer både viking og skandinavisk.

Dette stiller os over for et grundlæggende problem: Kan vi acceptere, at vi i dag bruger udtrykket viking i en betydning, det aldrig havde på den tid, vi bruger det om, når al god forskning forudsætter, at den terminologi, vi bruger, er både præcis og entydig? Forskningshistorien kan opvise talrige eksempler på, at manglende præcision i den anvendte terminologi har givet anledning til alvorlige fejlslutninger. Fra mit eget felt - og med relevans for vor forståelse for skandinavernes rolle i netop denne periode - er det kendteste eksempel nok de problemer, som kontroverser over betydningen af udtrykket rus' har skabt. Problemet er her, at der inden for et par hundrede år frem til omkring $1100 \mathrm{er}$ foregået en betydningsudvikling, hvor rus' fra i sin oprindelse at have været en funktionel term anvendt i skandinavisk (måske udelukkende svensk) sammenhæng, antog karakter af etnisk identifikator for skandinaver for, muligvis gen- 
nem en fase som fællesbetegnelse for nykristne i Rus'-riget, på ny at blive etnisk identifikator for den slavisktalende befolkning i Rusland. Her har især nationalistisk grebne forskere i tidens løb valgt at ignorere eller fornægte denne betydningsudvikling og har i stedet holdt fast i den nutidige betydning og har fortolket historien derudfra. ${ }^{41}$

I lyset af dette, hvad stiller vi så op med vore "vikinger" og den måde, hvorpå vi bruger dem, når det så åbenlyst er fejlagtigt. Rettelig burde vi som forskere afholde os fra at bruge udtrykket "vikinger" om skandinaver og kun bruge det med det betydningsindhold, det havde i sin samtid. I stedet bør vi, som vi gør i alle andre perioder, vi beskæftiger os med, bruge det for den tid ganske neutrale "skandinaver", hvis ikke den eller de grupper, vi skriver om, lader sig indsnævre ved et etnisk eller geografisk tilhørsforhold. Men kan vi overhovedet dreje hjulet tilbage til tiden, før Romantikkens forfattere førte os på afveje? Kan vi dæmme op for de kommercielle interesser, der i dag knytter sig til billedet af os alle som vikinger? Har vi viljen til at gøre det? ${ }^{42}$

\section{NOTER}

1. Fell 1986, s. 297-98.

2. Om de seks forekomster af "wicing" i digtet "The Battle of Maldon" og en forekomst i Wulfstan's "Sermo Lupi", samt den fra et traditionelt synspunkt overraskende manglende forekomst i visse andre oldengelske værker, se Fell 1986, s. 309-313. Belæggene i "The Battle of Maldon" i The Anglo-Saxon Minor Poems 1968, s. 7, 9-10, 16. Se også: http://classiclit.about.com/library/bl-etexts/anon/bl-anon-battleofmaldon-oe.htm.

3. Two of the Saxon Chronicles Parallel (787-1001 a.d.) 1889, s. 28-31, 50, 76.

4. Danmarks Runeindskrifter 1942, col. 379-81.

5. Sveriges runinskrifter 5 1940-1971, s. 90-91.

6. Danmarks Runeindskrifter 1942, col. 375-76.

7. Sudertredingen 2006, s. 33-39; se også: Gustavson, Snaedal, Stoklund \& Åhlén 1990, s. 23-26.

8. Sveriges runinskrifter 8 1949-51, 28-39.

9. Adam af Bremen 1978, s. 440-442.

10. Egils saga Skallagrímssonar 2001, s. 47. Se også: http://www.heimskringla.no/wiki/ Egils_saga_Skalla-Grímssonar.

11. En klassiker inden for denne genre er Askeberg 1944. Af senere bidrag kan nævnes: Hellberg 1980, Hofstra 2003 og Brink 2008.

12. Her fremstår Christine Fell som en prisværdig undtagelse, når hun i sin undersøgelse af oldengelsk "wicing" skriver: "What I wish to examine is not what a 'viking' was, nor what the etymology of vikingr may be, but simply what the Anglo-Saxons understood by the term wicing", Fell 1986, s. 295.

13. En fremtrædende og overbevist fortaler for netop sidstnævnte tolkning var den kendte norske specialist i norrønt sprog Finn Hødnebø, der, efter til sin egen tilfredshed at have afvist andre tolkninger, mente sig i stand til at "vise" gennem hvilke 
faser viking med udgangspunkt i personer fra Viken var endt med i henholdsvis engelsk og norsk at blive synonymt med en skandinavisk kriger/sørøver. Hødnebø 1987, s. 54. Netop med tanke på dette sted hos Hødnebø skriver Eric Christiansen, hos os kendt som Saxo-oversætter, at "this transfer of meaning depends on too many implausible factors: that the Viken people were called Vikingar rather than the better-attested Vikverjar, that they took the lead in piracy at a very early date, when all Baltic peoples had been at it from Roman times, and that no more descriptive word was available". I det hele taget finder Christiansen, at der i denne forbindelse er "many vik-words to play with". Generelt er Christiansen skeptisk med hensyn til at bruge udtrykket viking og valgte derfor ogsa at kalde sin bog, The Norsemen in the Viking Age. Den citerede tekst findes s. 2, n. 3. På den baggrund kan det heller ikke undre, at en anden vikingetidsforsker, Christine Fell, sikkert med et glimt i øjet skriver, at "anyone who proposes to add to the number of such studies [om ordet vikings etymologi] ought to offer an explanation and an apology", Fell 1986, s. 295.

14. Kiparsky 1934, s. 268-69.

15. Vasmer 1958, s. 206-207.

16. Goląb 1992, s. 381-82.

17. Widsith 1962, s. 23-27 (her s. 24). Se også: http://www.sacred-texts.com/neu/ascp/ a03_11.htm.

18. "after they had driven off the tribe of the Wicingas", jf. S.A.J. Bradley i Widsith 1982 efter netudgaven.

19. "after they had vanquished the Viking races", jf. Cosette Faust \& Stith Thompson i Widsith 1918, s. 19. Hertil må dog bemærkes, at det engelske "race" har et bredere betydsningsspektrum end dansk "race", således at det også kan bruges om grupper, der forenes af andre end racemæssige træk.

20. "after they had driven off the Heathobard tribe", jf. Bella Millet i nutidig netversion: http://www.soton.ac.uk/ enm/widsith.htm (set 20. juni 2011).

21. "Ic wæs mid Hunum ond mid Hreðgotum, mid Sweom ond mid Geatum ond mid Supdenum. Mid Wenlum ic wæs ond mid Wærnum ond mid wicingum ...”. Bemærk hvordan digtets "Ic wæs ... mid wicingum" nøje modsvarer runeindskriften G370, hvor en vis Helgi var "farin mip uikikum", jf. ovf.

22. Linjerne 331-35: "ÆEfter pære fyrde flota modgade, / Rubenes sunu. Randas bæron / sawicingas ofer sealtne mersc, / manna menio; micel angetrum / eode unforht. ”, jf. The Old English Exodus 1970, s. 57. Se også, http://www.sacred-texts.com/neu/ascp/ a01_02.htm.

23. Snorri Sturluson 1911, s. 108: "En er pau heldu austur í hafit pá komu at peim víkingar. Dat váru Eistr".

24. Snorri Sturluson 1911, s. 477: "Gerðist Hákon par landvarnarmaðr fyrir víkingum er mjök herjuðu á Danaveldi, Vindr og aðrir Austurvegs-menn ok svo Kúrir”. Håkon fik åbenbart hos kong Svend samme rolle som værn mod vikinger som Assur i runeindskriften U 617, jf. ovf.

25. Snorri Sturluson 1911, s. 534-35: "Pá er Sigurðr konungr siglði fyrir Spán. barsk pat at, at víkingar nokkurir, peir er fóru at féfangi, kómu í móti honum með galeiða her. En Sigurðr konungr lagði til orrostu við pá, ok hófu svá ina fyrstu orrostu við heiðna menn, ok vann af peim viii galeiðr $r$ ". I denne forbindelse citerer Snorre også skjalden Haldor Skvaldre, der også betegner disse galej-sejlere som vikinger. Efter at have 
passeret Gibraltar kommer Sigurd Jorsalfar i kamp mod endnu en sådan "vikingeflåde".

26. Knytlinga Saga 1919-25, s. 76: "meðan Haraldr hein hafði verit konungr yfir Danmörk, pá höfðu litt verit hegndir ósiðir, bæði innanlandsmönnum ok víkingum, er pá herjuðu í Danmörk, bæði Kúrir ok aðrir Austrvegsmenn". Se også Knytlinge Saga 1977, s. 48.

27. Ynguars saga víförla 1912, s. 20-21: "Bratt kom at peim ein eyin ok ueitti peim harda griothríd, enn peir hlífdu sier ok skutu j môti. En er víkingar fundu, at fast uar fyrir, pa tocu peir at blasa smidbelgium at ofni peim, sem elldr uar j, ok uard af puí micill gnyr". En svensk oversættelse findes i Larsson 1999, s. 113.

28. Kalkar 1907, s. 818.

29. Det første bind af Svenska Akademiens Ordbog kom allerede i 1898, mens det senest udkomne bind (2009) slutter med "tyna", se: http://g3.spraakdata.gu.se/saob (set 22. juni 2011).

30. En søgning i Diplomatarium Suecanum (Nationell arkivdatabas) giver da heller ikke noget resultat, se: http://www.nad.riksarkivet.se/SDHK?EndastDigitaliserat=false \&S $\mathrm{DHK}=\&$ DatumFran $=\&$ DatumTill $=\&$ Innehall $=\&$ Utfardare $=\&$ Utfardandeort $=\&$ Text $=$ viking $\&$ Brevtext $=$ true $\&$ Brevtext $=$ false $\&$ Extratext $=$ false $\&$ Sigill $=$ false $\&$ Kallor $=\&$ Spraket $=\&$ KommentarOchLitteratur $=\&$ Original $=$ true $\&$ Original $=$ false $\&$ Medel tidaAvskrifter $=$ true $\&$ MedeltidaAvskrifter $=$ false $\&$ MedeltidaRegest $=$ true $\&$ Medeltida Regest $=$ false $\&$ Brocman $=$ true $\&$ Brocman $=$ false $\&$ Hadorph $=$ true $\&$ Hadorph $=$ false $\&$ Peringskiold $=$ true $\&$ Peringskiold $=$ false $\&$ Ornhielm $=$ true $\&$ Ornhielm $=$ false $\&$ OvrM edeltidaAvskrifter $=$ true $\&$ OvrMedeltidaAvskrifter $=$ false $\&$ OvrMedeltidaRegest $=$ true $\&$ OvrMedeltidaRegest $=$ false $\&$ Tryckt $=\&$ TrycktRegest $=\&$ AvanceradSok $=$ False $($ søgt 22. marts 2012).

31. Aasen 1850, s. 596.

32. Peder Claussøn Friis (1545-1614) foretog sin oversættelse ca. 1600 på grundlag af et nu tabt håndskrift af Heimskringla. Efter Worms første udgave blev oversættelsen genoptrykt flere gange i samtiden.

33. Friis 1633. Jeg har ikke fundet det nødvendigt at præcisere, fra hvilke dele af Heimskringla originalteksterne stammer; men sammenhængen findes nemt ved at "google" på en sekvens af den norrøne tekst.

34. De øvrige forekomster i Friis' oversættelse, som ikke er gengivet her, findes i Friis 1633 , s. $16,17,22,49,52,56,59,69,71,94,98,105-06,129,168,175,183,188,201$ 02, 234 (flere eks.), 238, 269, 351, 388-89, 403, 461.

35. Lind 2006a, s. 64-71.

36. Jomswikinga-Sagan 1815.

37. Vikingabalken læses eksempelvis i Tegnér 1868, s. 112-16.

38. Worsaae kalder første del af sin bog fra 1863 om den danske erobring af England og Normandiet for "Vikinge-Tiden", Worsaae 1863, s. 3. Andre som P.A. Munch havde dog brugt betegnelsen tidligere (1851). For et nyligt norsk syn på begrebet vikingetiden se, Haavardsholm 2004.

39. Clarke \& Ambrosiani 1995, s. 118-20; Duczko 2004, s. 66-67.

40. Ved siden af en nu omfattende litteratur på russisk behandles hele dette kompleks i flere artikler i Franson, Svedin, Bergerbrant \& Androshchuk (udg.) 2007, og det vil blive yderligere belyst i en kommende publikation, Bjerg, Lind \& Sindbæk (udg.) 2012, der er resultat af en række seminarer, der blev holdt i 2007-09 i regi af det forskningsrådsstøttede, internationale Varangian Network. Om specielt varægernes 
rolle i kristningen af Rus' og den kristne indflydelse varægere har bragt videre mod nord, se Lind 2006b.

41. Lind 2010.

42. Mens russiske forskere før perestrojka og glaznost' i 1985 stort set aldrig brugte "vikinger” om skandinaver i Rus', bruges det i dag mindst lige så meget som i Vest, og arkæologer ved de store udgravninger langs "Vejen fra Varægerne til grækerne" er i dag i betydeligt omfang økonomisk afhængige af de aftaler, de indgår med turistindustrien, der markedsfører disse steder med tilstedeværelsen af "vikinger", Lind 2011, s. 217-21.

\section{LITTERATUR}

Aasen, I. 1850: Ordbog over det norske Folkesprog. Christiania.

Adam af Bremen 1978. I: W. Trillmich (udg.): Gesta Hammaburgensis ecclesiae pontificum. Darmstadt. The Anglo-Saxon Minor Poems 1968. E.v.K. Dobbie (udg.). New York \& London.

Askeberg, F. 1944: Norden och Kontinenten i gammal tid. Studier i forngermansk kulturhistoria. Uppsala.

Bjerg, L., J.H. Lind \& S.M. Sindbæk (udg.) 2012: From Goths to Varangians. Communication and Cultural Exchange Between the Baltic and the Black Sea. Aarhus.

Brink, S. 2008: Who were the Vikings? I: S. Brink \& N. Price (udg.): The Viking World. London, s. 4-7.

Christiansen, E. 2002: The Norsemen in the Viking Age. Oxford.

Clarke, H. \& B. Ambrosiani 1995: Towns in the Viking Age. London.

Danmarks Runeindskrifter 1941-42. L. Jacobsen \& E. Moltke (udg.). København.

Duczko, W. 2004: Viking Rus. Studies on the presence of Scandinavians in Eastern Europe. Leiden.

Egils saga Skallagrímssonar 2001. B. Einarsson (udg.). København.

Fell, C.E. 1986: Old English Wicing: A Question of Semantics. Proceedings of the British Academy 72. London, s. 295-316.

Franson, U., M. Svedin, S. Bergerbrant \& F. Androshchuk (udg.) 2007: Cultural interaction between east and west: Archaeology, artefacts and human contacts in northern Europe. Stockholm.

Friis, P.C. 1633: Snorre Sturlesøns Norske Kongers Chronica udsat paa Danske aff Peder Claussøn ...; nu nyligen menige Mand til Gaffn, igiennemseet, continuerit oc til Trycken forferdiget. Kjøbenhafn.

Goląb, Z. 1992: The Origins of the Slavs. A Linguist's View. Columbus.

Gustavson, Helmer, Thorgunn Snaedal, Marie Stoklund \& Marit Åhlén 1990: Runfynd 1988. Fornvännen, s. 23-42.

Hellberg, S. 1980: Vikingatidens víkingar. Arkiv för nordisk filologi 95, s. 25-88.

Haavardsholm, J. 2004: Vikingtiden som 1800-tallskonstruksjon. Oslo.

Heimskringla. I: http://www.snerpa.is/net/snorri/heimskri.htm.

Hofstra, T. 2003: Changing views on Vikings. Tijdschrift voor Skandinavistiek 24, s. 147-60.

Hødnebø, F. 1987: Who were the First Vikings? In: Proceedings of the Tenth Viking Congress. Oslo, s. 54.

Jomswikinga-Sagan, eller Historia om Kämparne frän Jomsborg 1815. M. Adlerstam \& L. Hammarsköld (red.). Stockholm.

Kalkar, O. 1907: Ordbog til det celdre danske Sprog IV. København; (også netversion http:// www.hist.uib.no/kalkar/). 
Kennedy, G.W. 1916: The Caedmon Poems. New York.

Kiparsky, V. 1934: Die gemeinslavischen Lehnwörter aus dem Germanishen. Helsinki.

Knytlinga saga 1919-25. I: C. Petersen \& E. Olson (udg.): Sogur Danakonunga. København.

Knytlinge Saga 1977. J.P. Ægidius (ovs.). København.

Larsson, M.G. 1999: Vikingar i Østerled. Stockholm.

Lind, J. 2006a: Goter og Göticisme. I: Goternes Sprog, Historie og Efterliv. Odense, s. 64-71; netudgave: http://static.sdu.dk/mediafiles//Files/Om_SDU/Institutter/Ihks/Projekter/Middelalderstudier/Goternes\%20Sprog\%20Historie\%20og\%20Efterliv.pdf.

Lind, J.H. 2006b: Reflections on church historians, archaeologists and early Christianity in Finland. I: Mervi Suhonen (red.): Arkeologian lumoa synkkyyteen. Artikkeleita Christian Carpelanin juhlapäiväksi = Lighting the darkness -- The attraction of archaeology. Papers in honour of Christian Carpelan. Helsinki, s. 68-74.

Lind, J. 2010: Problems of Ethnicity in the Interpretation of Written Sources on Early Rus'. Drevneishie gosudarstva vostochnoi Evropy 2009. Moskva, s. 184-96.

Lind, J. 2011: "Vikings" and the Viking Age. I: N.Y. Gvozdetskaja, I.G. Konovalova, E.A. Melnikova \& A.V. Podosinov (udg.). Stanzas of Friendship - Visy Druzhby. Studies in honour of Tatjana Jackson. Moskva, s. 201-22.

The Old English Exodus 1970. E.B. Irving (udg.). Hamden, Conn.

Sturluson, Snorri 1911: Heimskringla, Noregs konunga sogur, udg. F. Jónsson, København.

Sudertredingen 2006: Supplement till Gotlands runinskrifter 1. T. Snædal \& H. Gustavson (udg.), http://www.raa.se/cms/showdocument/documents/extern_webbplats/2006/juni/g_ sudertr.pdf.

Svenska Akademiens Ordbog 1898-(2009): I: http://g3.spraakdata.gu.se/saob.

Sveriges runinskrifter 5 1940-1971: Västergötlands runinskrifter, H. Jungner \& E. Svärdström (udg.). Stockholm. Sveriges runinskrifter 8 1949-51: Upplands runinskrifter 3, 1, E. Wessén \& S.B.F. Jansson (udg.). Stockholm.

Tegnér, E. 1868: Frithiofs Saga. Stockholm.

Two of the Saxon Chronicles Parallel (787-1001 a.d.) 1889: C. Plummer (udg.). Oxford.

Vasmer, M. 1958: Russisches etymologisches Wörterbuch 3. Heidelberg.

Widsith 1918. I: Cosette Faust \& Stith Thompson (red.): Old English Poems. Chicago \& New York.

Widsith 1962. K. Malone (udg.). København.

Widsith 1982. I: S.A.J. Bradley (udg.): Anglo-Saxon Poetry, translation. London. I: http:// www.wwnorton.com/college/english/nael/middleages/topic_4/widsith.htm.

Widsith: I: http://www.soton.ac.uk/ enm/widsith.htm.

Worsaae, J.J.A. 1863: Den Danske Erobring af England og Normandiet. Kjøbenhavn. Ynguars saga vífförla 1912. E. Olson udg. København. 


\section{"Vikings", the Viking Age and Viking Romanticism}

The aim of this article is to take a critical look at the term "Vikings", both as it was used in the time now referred to as the Viking Age, and as it is used today. It will also examine the degree to which Scandinavian activity during the Viking Age can justify this name being given to the epoch.

With regard to the term "Vikings", it is pointed out that, from the term's earliest known occurrence in Anglo-Saxon glossaries around AD 600 up until some point in time around 1300 when it seems to disappear from the Anglo-Saxon and Scandinavian languages, with Icelandic as a possible exception, it was unequivocally used in reference to pirates. In this respect it had no ethnic or geographic connotations but could, in Anglo-Saxon or Norse sources, be used in reference to anyone who behaved as a pirate, anywhere: Israelites crossing the Red Sea, Muslims encountering Norwegian crusaders in the Mediterranean, Caucasian pirates, Estonian and Baltic pirates in the Baltic Sea. Accordingly, a "Viking" was, in the earliest sources, not yet synonymous with a Scandinavian.

Furthermore, those who have attempted to derive an etymology for the word have omitted to take into consideration that at an early stage - in the first centuries AD it was borrowed into Slavonic with the meaning: hero and warrior. Consequently, these attempts were unsuccessful.

After having disappeared as a living word, it subsequently emerged from obscurity when Danish and Swedish historians began to compete with respect to creating the most glorious past for their respective countries and, in the process, became aware of the Icelandic sagas as a possible source. However, these historians no longer understood Old Icelandic and had to have the texts translated. The year 1633 saw the first major translation into Danish of Snorri's Heimskringla. It is apparent from this that the translator was convinced his readers would not know what a "Viking" was. Consequently, explanatory additions were inserted at virtually all its occurrences. These clearly demonstrate that, for the translator, the word still meant pirate and was, as yet, still not synonymous with a Scandinavian.

A "Viking" first became a Scandinavian with the advent of Romanticism, primarily thanks to the two Swedish poets Erik Gustaf Geijer (1783-1847), with the poem $V i-$ kingen, and Esaias Tegnér (1782-1846), with his new version of the Old Norse Friðpjoffs saga hins freekna. With the publication of these two works "Viking" became for the first time a household word and was now used exclusively in reference to Scandinavians; with this meaning it rapidly spread to other languages. Around the middle of the 19th century the word also began to be used in this sense by archaeologists and historians.

Soon the word "Viking" also became linked with the term for a period, the Viking Age, a period which was characterised by increasing Scandinavian activity outside Scandinavia. As the archaeological evidence could not, at that time, yet be dated with any precision, it was the evidence from written sources with respect to attacks on monasteries in the British Isles towards the end of the 8th century AD which, just as is still the case, came to mark the beginning of the Viking Age. While the written sources are today more 
or less the same as they were in the 19th century, the archaeological record continues to expand rapidly and the potential for dating is constantly being refined. As a consequence, we now know that Scandinavians were active both in the British Isles to the west and along the East European rivers long before the attacks on the above-mentioned monasteries.

Although the activities of Scandinavians in the east have never played a major role in general Viking studies, it is perhaps there that they had their most radical consequences for posterity.

Dendrochronological dates now show that Scandinavians settled at Staraja Ladoga around AD 750 from where, at an early point in time, they continued along the Volga towards the Caliphate. Later, however, towards the end of the 9th century, the route along the Dnepr to Byzantium became of greater importance. It was here that Scandinavians, known as "Rus", by establishing military bases intended to safeguard the trade route and, by forging alliances with the local populations, established the principality to which they gave their name and which subsequently became Russia: Undoubtedly the most marked consequence of Scandinavian activity during the Viking Age.
These trade-related bases, together with several rapidly growing trading places in the Scandinavian and Baltic areas, were part of a major long-distance trade network which conveyed goods between east and west. A characteristic feature of these trading places was that, apart from the local population, Scandinavians were the only group to be represented at more or less all of them. It seems that this long-distance trade network was based around Scandinavians. If justification is to be found for Scandinavian activity giving its name to an epoch in European history it must be in the form of this long-distance trade network, rather than war and plunder. At the same time, the temporal boundary for this period should be shunted back to the early 8 th century.

It is clear that our use of the term "Vikings" in reference to Scandinavians of that period is erroneous. In principle it should, in a research perspective, be abandoned in favour of "Scandinavians" or narrow contemporaneous ethnically- or geographically-based terms. But is this possible given that "Viking" has today become one of the most successful brands for Scandinavians and Scandinavia, and with powerful associated commercial interests?

John Lind

Center for Middelalderstudier Syddansk Universitet 